\title{
P02.153. Effectiveness of biofield therapy for patients with sickle cell disease in Africa
}

\author{
M Mikobi ${ }^{1}, K$ Suzuki ${ }^{*}$ \\ From International Research Congress on Integrative Medicine and Health 2012 \\ Portland, Oregon, USA. 15-18 May 2012
}

\section{Purpose}

Patients with sickle cell disease (SCD) in Africa have a high risk of premature death, mainly due to insufficient medical services. Some SCD patients in the first author's clinic experienced symptomatic improvement after administration of biofield therapy. The objective of this study was to evaluate the effectiveness of biofield therapy for SCD patients over a 4-year period.

\section{Methods}

We adopted Okada Purifying Therapy (OPT) as an intervention in this study. We formed a group of $20 \mathrm{SCD}$ patients aged 3-36 years (OPT group), and a control group $(n=20)$ of a matching age/gender profile from regular patients at the clinic. OPT was administered by certified practitioners approved by MOA International Corporation (http://www.moainternational.or.jp/) every weekday for one year. We examined participating patients' blood tests at the beginning and end of the 1-year period and ran a follow-up survey after 4 years.

\section{Results}

During the 1-year study period, the OPT group showed a significant improvement in the blood data: hemoglobin [median value from $6.3 \mathrm{~g} / \mathrm{dl}$ (25-75 percentile: $6.1-7.2)$ to $10.1 \mathrm{~g} / \mathrm{dl}$ (9.4-11.1), $\mathrm{p}<0.001$ ], total bilirubin [from $9.3 \mathrm{mg} / \mathrm{dl}$ (6.5-9.4) to $3.2 \mathrm{mg} / \mathrm{dl}(2.2-4.1), \mathrm{p}<0.001]$, and creatinine [from $1.1 \mathrm{mg} / \mathrm{dl}(0.9-1.7)$ to $0.7 \mathrm{mg} / \mathrm{dl}(0.6-0.8), \mathrm{p}<0.001$ ]. The control group had less improvement in hemoglobin [from 6.3g/dl (6.0-7.0) to 7.1g/dl (6.4-7.9), $\mathrm{p}=0.015$ ] and total bilirubin [from $9.1 \mathrm{mg} / \mathrm{dl}(6.8-9.3)$ to $6.8 \mathrm{mg} / \mathrm{dl}(6.2-$ 7.6), $\mathrm{p}=0.004$ ] than the OPT group $(\mathrm{p}<0.001)$; creatinine increased from $0.9 \mathrm{mg} / \mathrm{dl}(0.8-1.1)$ to $1.2 \mathrm{mg} / \mathrm{dl}(1.0-1.5)$ $(p<0.001)$. Three patients in the OPT group and all of the control group needed hospitalization once or more

${ }^{2}$ MOA Health Science Foundation, Tokyo, Japan

Full list of author information is available at the end of the article $(\mathrm{p}<0.001)$. After 4 years, 17 in the OPT group and 13 in the control group survived $(\mathrm{p}=0.27)$.

\section{Conclusion}

Considering the insufficient medical services, biofield therapy has possibly contributed to the positive outcomes, although the care given by the practitioners may also have had some influences. In conclusion, biofield therapy is considered safe and effective for SCD patients with various symptoms.

\section{Author details}

${ }^{1}$ The Medical Center for Sickle Cell Anemia, Kinshasa, Congo. ${ }^{2} \mathrm{MOA}$ Health Science Foundation, Tokyo, Japan.

Published: 12 June 2012

doi:10.1186/1472-6882-12-S1-P209

Cite this article as: Mikobi and Suzuki: P02.153. Effectiveness of biofield therapy for patients with sickle cell disease in Africa. BMC

Complementary and Alternative Medicine 2012 12(Suppl 1):P209.

Submit your next manuscript to BioMed Central and take full advantage of:

- Convenient online submission

- Thorough peer review

- No space constraints or color figure charges

- Immediate publication on acceptance

- Inclusion in PubMed, CAS, Scopus and Google Scholar

- Research which is freely available for redistribution

\section{Biomed Central}

